PENGARUH PENAMBAHAN TEPUNG TEMPE TERHADAP MUTU KECAP AIR KELAPA

\title{
The Effect of Tempe Flour Addition to the Quality of Coconut Water Sauce
}

\section{Silfia}

Balai Riset dan Standardisasi Industri Padang

Jl. Raya LIK Ulu Gadut No. 23 Telp. (0751) 72201 Fax.(0751) 71320 Padang 25164

e-mail : silfia6399@yahoo.com

Diterima : 19 September 2011, Revisi akhir: 22 November 2011

\section{ABSTRAK}

Telah dilakukan penelitian pengaruh penambahan tepung tempe terhadap mutu kecap air kelapa dengan tujuan mengurangi ketergantungan pada kacang kedele sebagai bahan baku pembuatan kecap dan memanfaatkan limbah air kelapa. Penelitian dilakukan dengan kombinasi perlakuan persentase tepung tempe $5 \%$ dan $10 \%$, dan perlakuan penambahan pengawet natrium benzoat $0,1 \mathrm{gr}$ dan $0,2 \mathrm{gr}$. Produk kemudian dianalisis kadar protein, cemaran logam $(\mathrm{Pb}, \mathrm{Cu}, \mathrm{Zn})$, cemaran mikroba dan uji organoleptik terhadap rasa, warna, aroma dan ketahanan simpan. Hasil penelitian menunjukkan bahwa penambahan tepung tempe $10 \%$ dengan pengawet natrium benzoat 0,2 gram memberikan hasil optimal dengan kadar protein $6,24 \%$, tekstur, rasa dan warna disukai serta tahan simpan lebih dari 8 minggu.

\section{Kata Kunci : Kecap air kelapa, tepung tempe, cemaran mikroba}

\section{ABSTRACT}

It had been done the research on effect of tempe flour addition to the quality of coconut water sauce with the aim of reducing dependence on soybean as a raw material of soy sauce and potential use of coconut water waste. The study was conducted with the combined treatment of tempe flour percentage (5\% and 10\%), and the addition of the preservative sodium benzoate treatment $(0.1 \mathrm{~g}$ and $0.2 \mathrm{~g})$. The protein level, metal contamination ( $\mathrm{Pb}, \mathrm{Cu}, \mathrm{Fe}, \mathrm{Zn}$ ), microbial contamination and organoleptic tests of the flavor, color, fragrance and product stability during storage were analyzed. The results showed that the addition of tempe flour of $10 \%$ with 0.2 grams of the preservative sodium benzoate provide optimal results with a protein content of $6.24 \%$, texture, flavor, and color were preferred and the product keep persitst for more than 8 weeks.

\section{Keywords: Coconut water sauce, tempe flour, microbial contamination}

\section{PENDAHULUAN}

Indonesia merupakan negara yang memiliki luas areal dan hasil kelapa terbesar di dunia. Kelapa (Cocos nucifera $L$ ) adalah tumbuhan pohon termasuk family arecaceae dan disebut juga suku pinangpinangan. Di Indonesia kelapa merupakan tanaman industri yang mempunyai nilai penting baik dari segi gizi maupun dari segi ekonomis. Kelapa merupakan tanaman serbaguna, mulai dari daun, pelepah, batang, akar dan buah. Buah kelapa berbentuk bulat panjang dengan ukuran kurang lebih sebesar kepala manusia.
Luas areal tanaman kelapa (Sumbar Dalam Angka, 2010) yaitu $76.888 \mathrm{Ha}$ dengan jumlah produksi 91.920 ton, di Sumatera Barat daerah produksi terbanyak adalah Kabupaten Padang Pariaman produksi kelapa rata-rata per tahun 62.283,6 ton dan air kelapa sebanyak 16.872.627,24 liter. Komposisi buah kelapa terdiri dari sabut $33 \%$, tempurung $12 \%$, daging buah $28 \%$, dan air $25 \%$.

Kandungan gizi air kelapa, 4,7 persen total padatan, 2,6 persen gula, 0,55 persen protein, 0,74 persen lemak, serta 0,46 persen mineral (Arsenal, 2009). Karena komposisi gizi yang demikian, 
maka air kelapa menurut Yolianingsih (2011), memiliki khasiat untuk kesehatan. seperti dapat mengobati diare, muntaber, membersihkan saluran pencernaan, memperbaiki sirkulasi darah, meningkat kan kekebalan tubuh, dapat mempercepat naiknya trombosit dan berpotensi dijadikan bahan baku produk pangan, antara lain pembuatan minuman, jelly, alkohol, dektrin, cuka, nata de coco, dan kecap.

Kecap merupakan salah satu jenis bumbu masakan yang banyak disukai. Biasanya digunakan untuk campuran bubur, bakso, soto, sate dan makanan lainnya. Kecap pada umumnya dibuat dengan fermentasi biji kedelai. Kecap dari air buah kelapa dibuat dari proses penguapan air kelapa yang ditambah bumbu dan gula enau. Biasanya ditambahkan kedelai sebagai tambahan protein pada kecap, dengan kandungan protein kedelai $35 \%$.

Penambahan protein pada kecap air kelapa biasanya digunakan kedelai, namun kedelai mengandung senyawa anti gizi. Senyawa anti adalah suatu senyawa yang terdapat dalam beberapa bahan pangan yang dapat mengganggu penyerapan zat gizi didalam tubuh pada saat pangan tersebut dikonsumsi (Anonim, 2011). Salah satu upaya penambahan protein adalah dengan mengganti bahan tambahan dengan tempe kedelai karena protein yang dikandungnya lebih tinggi dari protein biji kedelai yaitu 43,31\% dari berat kering (Kusumawardani, 2011). Kelemahan tempe yaitu mudah rusak, maka harus diproses menjadi bubuk agar mudah dalam penggunaannya. Proses pembuatan kecap dari air kelapa sama dengan pembuatan kecap dari kacang kedelai, bahkan jauh lebih mudah dan tidak memakan waktu yang terlalu lama (Anonim, 2006).

\section{BAHAN DAN METODE PENELITIAN}

\section{Bahan dan Peralatan}

Bahan yang digunakan dalam penelitian ini terdiri dari air kelapa, bahan untuk proses seperti gula enau, tepung tempe, garam, dan rempah (bumbu), natrium benzoat, dan kemasan serta bahan kimia untuk analisis kadar protein
Peralatan yang digunakan dalam penelitian ini terdiri dari panci email, pisau, talenan, wajan, nyiru, waskom, kain saring, botol kecap, kompor, sendok pengaduk, tempat peniris, sendok penjepit, timbangan, oven, dan sealer serta peralatan untuk pengujian kadar protein, cemaran logam $\mathrm{Pb}, \mathrm{Cu}, \mathrm{Zn}$.

\section{Metode Penelitian}

\section{Rancangan Percobaan}

Penelitian dilakukan menggunakan Rancangan Acak Lengkap (RAL) secara faktorial yaitu :

Faktor A : Persentase tepung tempe

$$
\text { A1 }=\text { Tepung tempe } 5 \%
$$$$
\text { A2 = Tepung tempe } 10 \%
$$

Faktor B : Penambahan pengawet natrium benzoat $\mathrm{B} 1=$ Natrium benzoat $0,1 \mathrm{~g}$ $\mathrm{B} 2=$ Natrium benzoat $0,2 \mathrm{~g}$

\section{Pelaksanaan}

Proses pembuatan kecap air kelapa adalah sebagai berikut: Air kelapa disaring, ditambahkan gula enau, bumbu, tepung tempe, garam, dimasak, tambahkan natrium benzoat, didinginkan, disaring dan dikemas dalam botol kecap. Diagram alir pembuatan kecap air kelapa seperti pada Gambar 1.

\section{Analisis}

Analisis kimia dilakukan terhadap kecap air kelapa meliputi kadar protein, kadar abu, cemaran logam $\mathrm{Pb}, \mathrm{Cu}, \mathrm{Zn}$. Uji organoleptik dilakukan oleh panelis meliputi rasa, warna dan aroma dengan skala numerik sebagai berikut :

5 = sangat suka,

4 = suka

3 = biasa

2 = kurang suka

1 = tidak suka

Pengamatan ketahanan simpan di lakukan secara visual terhadap rasa, warna, dan aroma kecap air kelapa setiap 2 minggu selama 2 bulan penyimpanan. 

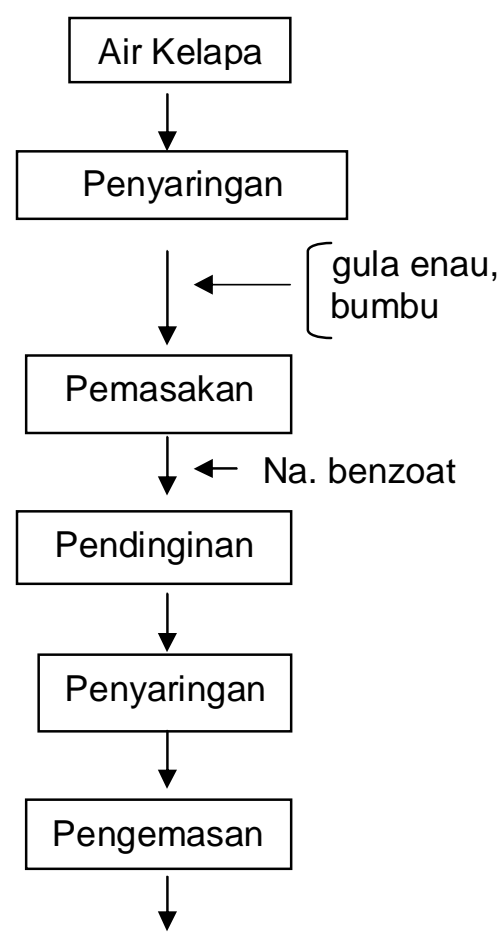

Kecap Air Kelapa

Gambar 1. Diagram alir pembuatan kecap air kelapa.

\section{HASIL DAN PEMBAHASAN}

\section{Kadar Protein}

Hasil analisis kadar protein seperti terlihat pada Gambar 2, dimana kadar protein kecap air kelapa pada perlakuan A2B2 (persentase tepung tempe 10\% dengan penambahan natrium benzoat 0,2 g) memberikan kadar protein tertinggi dibandingkan dengan perlakuan lain yakni $6,24 \%$ sedangkan kadar protein terendah didapatkan pada perlakuan A1B1 (persentase tepung tempe $5 \%$ dengan penambahan natrium benzoat $0,1 \mathrm{~g}$ ) yakni $4,79 \%$. Kadar protein kecap air kelapa hasil análisis (4,79\%-6,24\%) lebih tinggi dibandingkan dengan kadar protein kecap yang dipersyaratkan sesuai SNI 01-35431999 tentang kecap kedelai yaitu mínimum 4,0\%, (Badan Stándardisasi Nasional, 1999). Penambahan tepung tempe 10\% menghasilkan kecap mutu I dan penambahan tepung tempe $5 \%$ menghasilkan kecap mutu II, hal ini disebabkan karena kandungan protein biji kedelai $35 \%$ lebih rendah dari kandungan protein pada tempe yaitu 43,31\% (Kusumawardani, 2011)

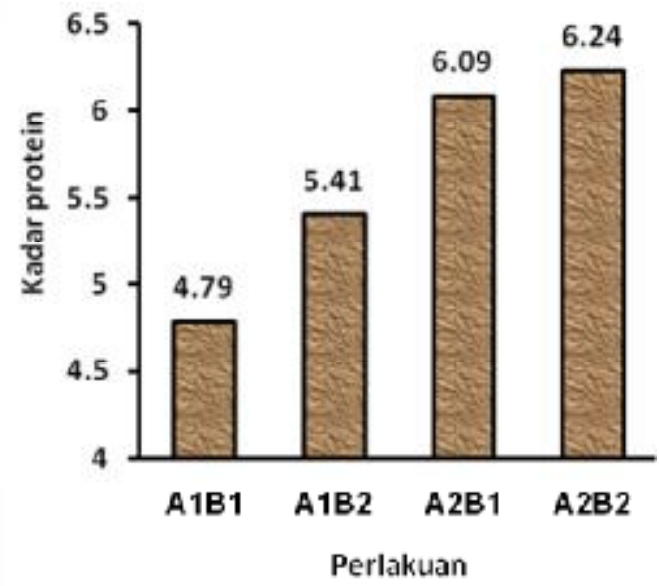

Gambar 2. Hasil analisis kadar protein kecap air kelapa.

Menurut Winarno (1997), pada tepung tempe terdapat senyawa glikoprotein yang merupakan jenis protein konyugasi mengandung bagian asam amino yang terikat pada karbohidrat. Protein tempe lebih mudah dicerna oleh tubuh dibandingkan dengan protein kedelai yang mengandung anti gizi (Kusumawardani, 2011). Umumnya kadar protein dalam bahan pangan menentukan mutu bahan itu sendiri, semakin tinggi kandungan protein suatu bahan pangan maka semakin tinggi mutu bahan pangan tersebut (Suryati, 1999).

\section{Kadar Abu}

Hasil analisis kadar abu seperti terlihat pada Gambar 3, dimana kadar abu kecap air kelapa pada perlakuan A2B2 (persentase tepung tempe $10 \%$ dengan penambahan natrium benzoat 0,2 g) memberikan kadar abu paling tinggi dibandingkan dengan perlakuan lain yakni $0,98 \%$ sedangkan kadar abu terendah didapatkan pada perlakuan A1B2 (persentase tepung tempe $5 \%$ dengan penambahan natrium benzoat $0,2 \mathrm{~g}$ ) yakni 0,75\%. Kadar abu kecap air kelapa berkisar antara 0,75\%-0,98\%, semakin banyak tepung tempe yang ditambahkan maka semakin tinggi kadar abu kecap air kelapa, hal ini disebabkan oleh 
peningkatan kadar abu yang berasal dari tempe, kadar abu tempe $\pm 4,3 \%$ (Cahyadi, 2006).

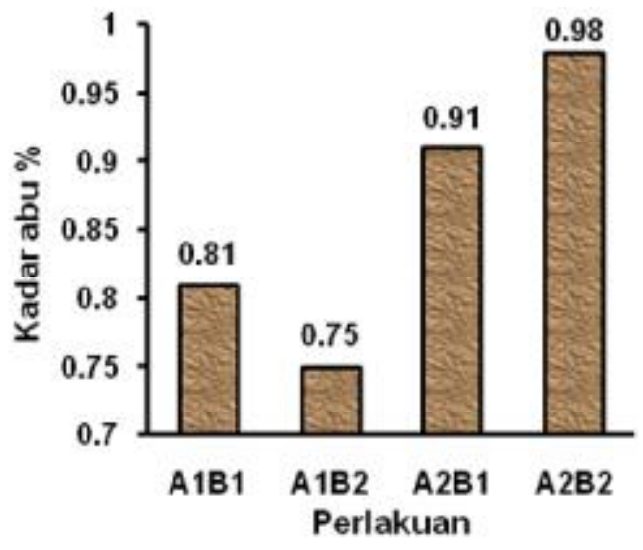

Gambar 3. Hasil analisis kadar abu kecap air kelapa

Kadar abu tempe diduga dari vitamin yang terbentuk oleh bakteri yang tumbuh selama fermentasi tempe khususnya vitamin B12 (Ferlina, 2009). Selanjutnya dijelaskan bahwa selama fermentasi tempe jumlah Vitamin B12 meningkat diproduksi oleh bakteri Klebsiella pneumonia. Vitamin B12 adalah suatu vitamin yang sangat kompleks molekulnya, yang selain mengandung unsur $\mathrm{N}$ juga mengandung sebuah atom cobalt (Co) yang terikat mirip dengan besi terikat dalam hemoglobin atau magnesium dalam klorofil (Winarno, 2002). Selama fermentasi tempe kedelai juga mengalami pembentukan vitamin B12, sehingga kenaikan jumlah abu diduga berasal dari nitrogen dan cobalt (Co pada vitamin B12) yang terkandung dalam vitamin B kompleks tersebut.

\section{Cemaran logam $\mathrm{Pb}$}

Hasil analisis cemaran logam $\mathrm{Pb}$ untuk semua perlakuan kecap air kelapa adalah tidak terdeteksi, artinya memenuhi standar mutu SNI 01-3543-1999 tentang kecap kedelai. Cemaran logam $\mathrm{Pb}$ yang dipersyaratkan adalah maks 1,0 ppm (Badan Standardisasi Nasional,1999). Hal ini disebabkan karena peralatan yang digunakan dalam pembuatan kecap adalah stainlessteel, sementara dari bahan baku air kelapa menurut Arsenal (2009), tidak mengandung logam $\mathrm{Pb}$ karena air kelapa dapat menetralisir logam-logam berat, termasuk logam berat yang berasal dari tepung tempe dan gula enau.

\section{Cemaran logam $\mathrm{Cu}$}

Hasil analisis cemaran logam $\mathrm{Cu}$ seperti terlihat pada Gambar 4.

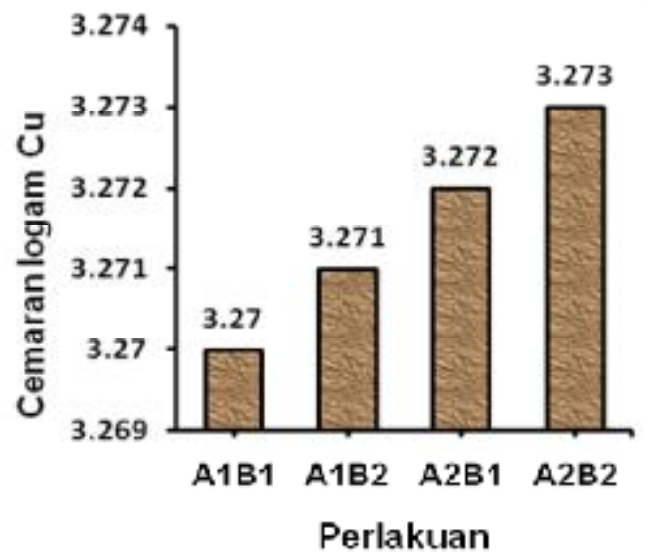

Gambar 4. Hasil analisis cemaran logam Cu kecap air kelapa.

Kecap air kelapa pada perlakuan tepung tempe $10 \%$ dengan penambahan natrium benzoat $0,2 \mathrm{~g}$ (A2B2) memberikan cemaran logam $\mathrm{Cu}$ yang paling tinggi 3.273 ppm dibandingkan dengan perlakuan lain, perlakuan tepung tempe $5 \%$ dengan natrium benzoat $0,1 \mathrm{~g}$ (A1B1) memberikan cemaran logam $\mathrm{Cu}$ lebih rendah dibanding perlakuan lainnya yakni 3,270 ppm. Cemaran logam hasil análisis lebih rendah dibandingkan dengan cemaran logam kecap kedelai yang dipersyaratkan sesuai SNI 01-3543-1999 yaitu maksimum 30,0 ppm (Badan Standardisasi Nasional, 1999). semakin tinggi tepung tempe yang ditambahkan maka semakin tinggi cemaran logam $\mathrm{Cu}$ karena kemampuan air kelapa untuk menetralisir logam-logam akan berkurang dan sebaliknya (Arsenal, 2009).

\section{Cemaran logam Zn}

Hasil analisis cemaran logam $\mathrm{Zn}$ kecap air kelapa seperti terlihat pada Gambar 5. Cemaran logam $\mathrm{Zn}$ berkisar antara 3,41$3.58 \mathrm{ppm}$. Kecap air kelapa pada perlakuan tepung tempe $10 \%$ dengan penambahan natrium benzoat $0,2 \mathrm{~g}$ (A2B2) memberikan 
cemaran logam seng atau $\mathrm{Zn}$ yang paling tinggi yaitu 4.58 ppm dibandingkan dengan perlakuan lainnya. Perlakuan tepung tempe $5 \%$ dengan natrium benzoat $0,2 \mathrm{~g}$ (A1B2) memberikan cemaran logam $\mathrm{Zn}$ lebih rendah yakni 3,41 ppm. Cemaran logam kecap hasil análisis lebih rendah dibandingkan dengan cemaran logam kecap yang dipersyaratkan sesuai SNI 013543-1999 tentang kecap kedelai, maksimum 40 ppm (Badan Standardisasi Nasional, 1999).

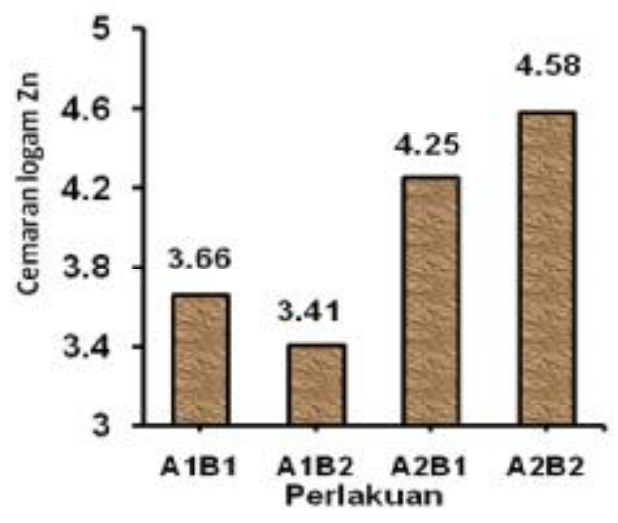

Gambar 5. Hasil analisis cemaran Logam Zn kecap air kelapa

Selanjutnya menurut Soemirat (2003), logam berat merupakan bahan yang berbahaya apabila terkonsumsi melebihi ambang batasnya karena dapat merusak atau menurunkan fungsi sistem syaraf pusat, merusak komposisi darah, paruparu, ginjal dan organ vital lainnya karena logam berat bersifat bioakumulasi dalam tubuh.

\section{Uji Organoleptik}

\section{Rasa}

Berdasarkan uji organoleptik yang dilakukan panelis diperoleh hasil yang berbeda nyata terhadap nilai rasa kecap air kelapa. Nilai rasa disukai panelis seperti terlihat pada Gambar 6. Hasil uji organoleptik rasa kecap air kelapa berkisar antara 3.2-3.75. Semakin banyak tepung tempe yang ditambahkan semakin disukai oleh panelis. Hal ini dikarenakan tepung tempe mengandung asam amino leusin dan lisin serta enzim-enzim seperti protease, lipidase, dan amilase yang sangat diperlukan untuk menghasilkan kecap dengan cita rasa yang enak, lezat, dan khas (Lordbroken, 2011).

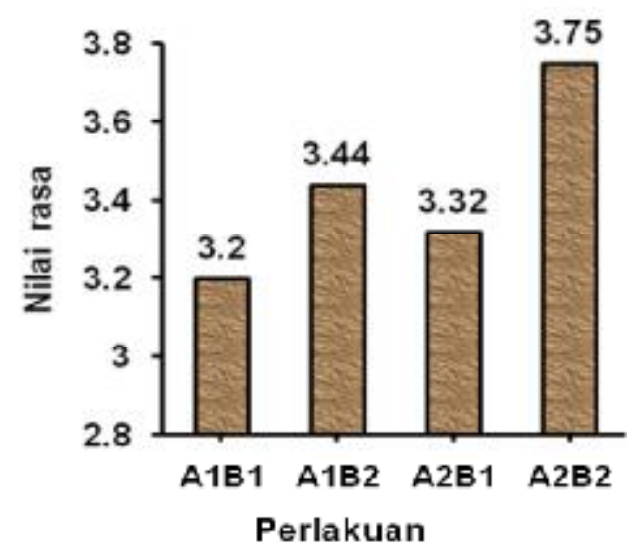

Gambar 6. Hasil uji organoleptik rasa kecap air kelapa

Menurut Winarno (2002), rasa adalah sensasi yang diterima oleh alat pencecap kita yang berada dirongga mulut. Rasa ditimbulkan oleh senyawa yang larut dalam air yang berintegrasi dengan reseptor pada lidah dan indera perasa (trigeminal) pada rongga mulut.

\section{Warna}

Berdasarkan uji organoleptik terhadap warna kecap air kelapa memberikan hasil berbeda tidak nyata terhadap warna. Nilai warna berkisar 3,56-3,80 (disukai) seperti terlihat pada Gambar 7. Warna kecap air kelapa untuk semua perlakuan hampir sama dengan warna kecap kedelai karena warna dari air kelapa akan mengalami peristiwa perubahan reaksi kimia dan fisika yang sama dengan kecap kedelai. Menurut Winarno (1983), dalam pengolahan pangan warna hasil akhir biasanya diperoleh dari kombinasi beberapa peristiwa perubahan warna karena reaksi kimia dan fisika.

Menurut De Man (2003), warna penting baik bagi makanan yang diproses maupun yang tidak diproses dan memegang peranan penting dalam keterterimaan makanan, selain itu warna 
dapat memberi petunjuk mengenai perubahan kimia dalam makanan seperti pencoklatan dan pengkaramelan.

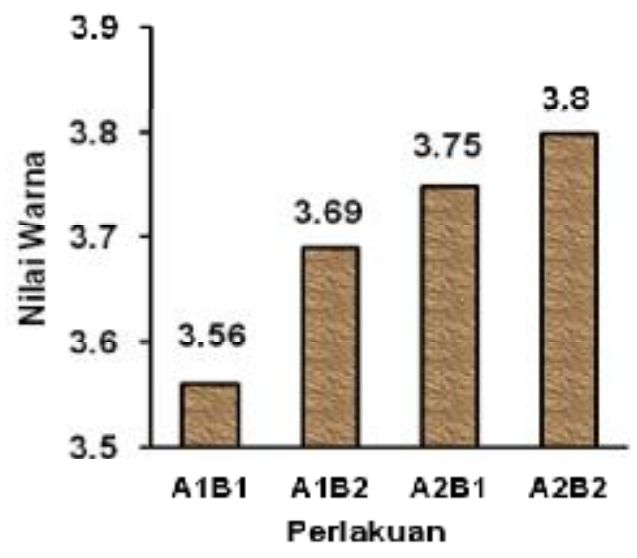

Gambar 7. Hasil uji organoleptik warna kecap air kelapa

Winarno (2002), mengatakan bahwa warna merupakan atribut mutu utama pada penampakan produk pangan dan merupakan karakteristik penting mutu produk pangan, penggunaannya sebagai penentu kualitas. Warna juga digunakan sebagai indikator kerusakan biologis atau fisiokimia, dan penggunaan warna untuk memprediksi karakteristik parameter lainnya.

\section{Aroma}

Berdasarkan uji organoleptik yang dilakukan panelis diperoleh hasil yang berbeda nyata terhadap nilai aroma kecap air kelapa. Nilai aroma berkisar antara 3.35- 3.44 (suka) seperti Gambar 8.

Dari gambar 8 terlihat bahwa aroma untuk semua perlakuan disukai oleh panelis, hal ini disebabkan karena kecap air kelapa dan kecap kedelai sama-sama memakai kedelai. Menurut De Man (2003), aroma merupakan sisi penting dari mutu makanan kadang-kadang lebih dari bau, rasa dan warna. Menurut Wijaya ( 2009), aroma adalah sensasi dari senyawa volatil yang diterima oleh rongga hidung. Aroma makanan banyak menentukan kelezatan bahan makanan dan berkaitan dengan alat panca indera hidung dan tidak bergantung pada penglihatan (Winarno, 2002).

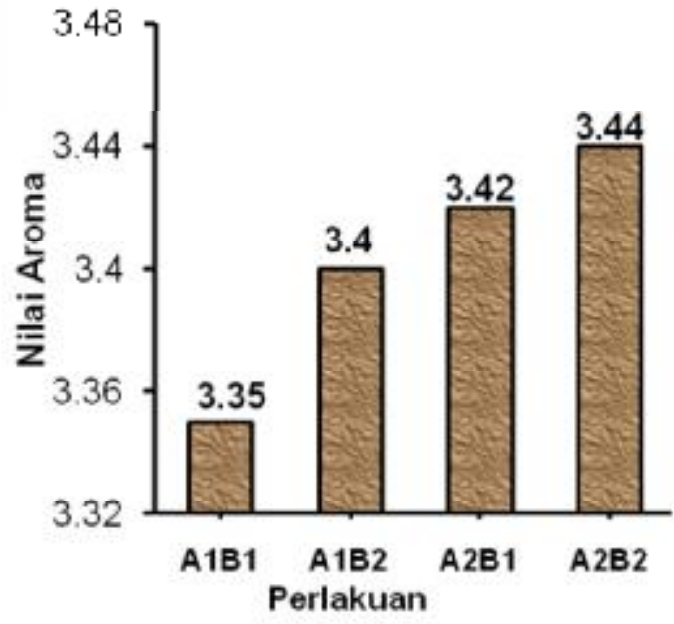

Gambar 8. Hasil uji organoleptik aroma kecap air kelapa

Selanjutnya Wijaya (2009), menambahkan bahwa aroma makanan yang disebarkan oleh produk makanan menjadi daya tarik yang sangat kuat dan mampu meransang indera penciuman sehingga dapat membangkitkan selera. Timbulnya aroma makanan disebabkan oleh terbentuknya senyawa yang mudah menguap (senyawa volatil).

Selanjutnya De Man (2003), mengatakan bahwa aroma dapat dikenali bila berbentuk senyawa yang mudah menguap (senyawa volatil), dimana molekul komponen tersebut menyentuh silia sel olfaktori dan diteruskan ke otak dalam bentuk impuls listerik. Kadar yang ditangkap manusia sangat rendah dan mampu mendeteksi dan membedakan lebih kurang 16 juta jenis aroma dan ini lebih kecil dibandingkan dengan makhluk lain. Aroma tidak tergantung pada penglihatan, pendengaran dan sentuhan.

\section{Pengamatan Penyimpanan}

Pengamatan daya simpan kecap air kelapa dilakukan secara visual terhadap warna, rasa, dan tekstur setiap 2 minggu selama 2 bulan penyimpanan. Hasil pengamatan dapat dilihat Tabel 1. Setelah 8 minggu (2 bulan) penyimpanan, pengamatan terhadap kecap air kelapa untuk semua perlakuan masih baik (normal) dan belum ditumbuhi jamur. Hal ini dikarenakan dalam proses pembuatan kecap dari air kelapa ini ditambahkan 
dengan natrium benzoat yang berfungsi sebagai pengawet. Zat pengawet adalah bahan yang ditambahkan dalam makanan dengan tujuan menghambat kerusakan oleh mikroorganisme (bakteri, khamir, kapang) sehingga proses pembusukan atau pengasaman atau penguraian dapat dicegah sekaligus menjaga nutrisi makanan.

Selain itu, ketahanan terhadap penyimpanan produk kecap dikarenakan proses pemasakan yang cukup lama, sesuai dengan pendapat Syarief dan Halid (1991) tindakan yang tepat untuk mencegah pertumbuhan jamur (kapang) adalah dengan adanya pengeringan seperti pemasakan yang dapat mengurangi kadar air sehingga kapang tidak dapat tumbuh.

Selanjutnya Destrosier (1988), menyatakan ketahanan simpan dipengaruhi oleh beberapa faktor yaitu keadaan pengemasan disamping itu juga pengaruh yang ditimbulkan oleh jenis dan kualitas bahan baku, metoda dan keefektifan pengolahan, jenis dan suhu dan kelembaban dapat diminimalisasi selama penyimpanan.

Tabel 1. Hasil Pengamatan Rasa, Warna dan Aroma Kecap Air Kelapa Selama Penyimpanan.

\begin{tabular}{|c|l|l|l|l|l|}
\hline $\begin{array}{c}\text { Lama } \\
\text { Penyimp } \\
\text { anan } \\
\text { (Minggu) }\end{array}$ & \multirow{2}{*}{$\begin{array}{c}\text { Spesifi } \\
\text { kasi }\end{array}$} & \multicolumn{4}{|c|}{ Perlakuan } \\
\cline { 3 - 6 } 2 & A1 & A1 & A2 & A2 \\
B1 & B2 & B1 & B2 \\
\hline \multirow{3}{*}{4} & Rasa & N & N & N & N \\
& Warna & N & N & N & N \\
& Aroma & N & N & N & N \\
\hline \multirow{3}{*}{4} & Rasa & N & N & N & N \\
& Warna & N & N & N & N \\
& Aroma & N & N & N & N \\
\hline \multirow{3}{*}{6} & Rasa & N & N & N & N \\
& Warna & N & N & N & N \\
& Aroma & N & N & N & N \\
\hline \multirow{2}{*}{8} & Rasa & N & N & N & N \\
& Warna & N & N & N & N \\
& Aroma & N & N & N & N \\
\hline
\end{tabular}

Keterangan: $\mathrm{N}=$ Normal

\section{KESIMPULAN DAN SARAN}

\section{Kesimpulan}

Dari penelitian yang telah dilakukan diperoleh kesimpulan sebagai berikut :

1. Mutu kecap air kelapa dipengaruhi oleh penambahan tepung tempe dengan pengawet benzoat A2B2 memberikan hasil optimal dengan kadar protein $6,24 \%$, kadar abu $0,98 \%$, cemaran logam $\mathrm{Pb}$ untuk semua perlakuan tidak terdeteksi, cemaran logam $\mathrm{Cu} 3,273$ ppm dan cemaran logam Zn 4,58 ppm, tekstur, rasa dan warna disukai serta tahan simpan lebih dari 8 minggu.

2. Kecap air kelapa berdasarkan hasil analisis layak untuk di konsumsi karena mutu dari produk sesuai dengan SNI kecap kedelai (SNI 013543-1999)

\section{Saran}

Untuk penelitian lanjutan disarankan agar proses pengemasan kecap air kelapa dilakukan dengan pengemasan vakum sehingga daya tahan kecap dapat dipertahankan lebih lama.

\section{DAFTAR PUSTAKA}

Anonim, 2006, Khasiat Kedelai dan Teknologi, Buku Elektrolnik Pangan.

Bappeda dan BPS Propinsi Sumatera Barat, 2010. Sumatera Barat Dalam Angka. Kerjasama Badan Perencanaan dan Pembangunan Daerah dan Badan Pusat Statistik Propinsi Sumatera Barat. Padang.

Anonim, 2010. Protein. http:/www iptek.net.id. Dikunjungi pada tanggal 7 September 2011.

Arsenal, 2009. Kandungan Gizi Air Kelapa http:// wordpress.com/ kandungan air kelapa. Dikunjungi pada tanggal 9 Oktober 2011.

Badan Standardisasi Nasional, 1999. SNI 01-3543-1999 tentang Kecap Kedele. Badan Standardisasi Nasional Indonesia. 
Cahyadi, 2006. Kadar Abu Bahan, Bandung, Bumi Aksara.

De Man, J.M., 2003. Kimia makanan. Bandung, Penerbit ITB.

Destrosier, W.N., 1988. Teknologi pengawasan pangan. Edisi ke III. Jakarta, Penerbit Universitas Indonesia.

Ferlina, 2009. Kedelai Khasiat dan Teknologi. Bandung, Bumi Aksara.

Kastanya, L., 2008, Natrium Benzoat, http://yongkikastanyalluthana.wordpres s.com. Dikunjungi pada tanggal 12 September 2011.

Kusumawardani, W., 2011. Proses Produksi Pemanfaatan Air Kelapa Sebagai Produk Olahan Kecap dengan Penambahan Bubuk Kedelai dan Bubuk Tempe, http://digilib.uns.ac.id/abstrakpdf_2056 2 Dikunjungi pada tanggal 7 September 2011.

Lordbroken, 2011. Serba-serbi Pembuatan dan Kandungan Kecap, seri IImu dan teknologi pangan. http://lordbroken. wordpress.com. Dikunjungi pada tanggal 7 September 2011.
Soemirat, 2003. Kadar Logam Berat dalam tempe yang beredar di pasaran. http;//ttg. Dikunjungi pada tanggal 11 September 2011.

Suryati, A., 1999. Pengetahuan bahan dan produk industri kecil. Pengolahan Pangan, BBIHP, Bogor.

Syarief, R., \& Halid, H., 1991. Teknologi penyimpanan pangan. Bogor, Penerbit Arcan.

Wijaya, H. 2009. Sensasi Rasa Foodreview Indonesia. Vol. IV, Bogor.

Winarno, F.G., 1997. Kimia pangan dan gizi. Jakarta, PT. Gramedia Pustaka Utama.

Winarno, F.G., \& Fardiaz, 1983. Teknologi Pangan. Jakarta, PT. Gramedia Pustaka Utama.

Winarno, F.G., 2002. Kimia pangan dan gizi. Jakarta, PT. Gramedia Pustaka Utama.

Wiryadi, R., 2007. Analisis Kadar Abu. Jakarta, PT. Gramedia Pustaka Utama. 